Paedintrica Indonesiana $15: 255$ - 261. Sept. - Oct. 1975. 255

From the Department of Chibd Health, Medical School University of Indonesia, Jakaartio

\title{
Effect of Low Lactose Milk Eiwit Melk (E.M.) on Protein Calorie Malnutrition
}

\section{$8 y$}

SUHARJONO, WILA WIRYA, I.G.N., SAMSUDIN, SUNOTO, Z. SULAIMAN and SLTEDJO

\begin{abstract}
During 11/2 years, from January 1972 until July 1973, 55 P.C.M. children hospitalieed in the Department of Child Health, Medical School, University of Indomesia/Dr. Tjipto Mangunkusumo Gemeral Hospital, were involved to this study. Self-prepaaned "Eiwit Melk (E.M.)" contiining protein $2.7 \%$, aarbohydrate (lactose) $1.4 \%$, fat $2.2 \%$ and aalories 600 , was used. Thirty children were treated with E.M, and 25 children as controlled, i.e. treated with E.M. + Iactose 3.4\% (E.M.L.).

The results of the clinical trial as expressed with the increase of body weight, were excellent in $85.7 \%$ and good in 14.3\%, whereas the rcsults in the controlled growp were excellent in only $9.1 \%$, good in $36.4 \%$ and poor in $54.5 \%$.
\end{abstract}

From these excellent results, low lactose milk formula might bo recommended in treating children with P.C.M.

Received 13th. Juli 1974. 


\section{Introductivn}

Intestinal biopsy study reveals that abnormal changes in the mucosa (villi) of the upper intestine occur in Protein Calorie Malnutrition (P.C.M.), especivalily in the severe form (Suharjono at al., 1970). The enzyme lactase is produced and acts in the brushborder of the microvilli. Stanfield (1965) found in oniy 2 of 11 severe PCM Chilldren, where lactase levels were within the normal range. Lactase deficiency in severe PCM due to a change in villous pat tern might cause lactose intolerance.

Nineiteen $(86.4 \%)$ of the 22 children studied in Jakarta suffering from PCM showed flat blood glucose curves following ingestijn of lactose (Sunoto et al., 1973). Due to atrophy of the villi of the intestinal mucosa in PCM disaccharidase deficiency may occur which may cause secondary sugar initolerance. So, in treating PCM children, a lactose free or lactose low diet might be more reasonable (Suharjono et all, 1971).

Thils paper is dealing with the results of our study on the effect of "low lactose milk" on PCM children.

\section{Materials and methods.}

During $1 \frac{1}{2}$ years, from January 1972 until July 1973, 55 PCM children hospitalized in the Departinent of Child Health, Medical School, Universiity of Indonestia/Dr. Tjupto Mangunkusumo General Hospital, were involvell to this study. We used self-prepared "Eiwit Melk" (E.M.) containuing $1.4 \%$ lactose. The main compasition of this formula $1 \mathrm{~L}$ solution is as follows.

$\begin{array}{ll}\text { - protein } & : 2.7 \% \\ \text { - carbohydrate (lactose) } & : 1.4 \% \\ \text { - fat } & : 2.2 \% \\ \text { - calories } & : 600\end{array}$

Thirty children were treated with E.M., and as a control of this study we put the other 25 PCM children on "Eitwit Melk" + lactose 3.4\% (E.M.L.) where the main composition in $1 \mathrm{~L}$ solution is as follows :

$\begin{array}{ll}\text { - protein } & : 2.7 \% \\ \text { - carbohydrate (lactose) } & : 4.8 \% \\ \text { - fat } & : 2.2 \% \\ \text { - calonies } & : 736\end{array}$

The other 30 patients were excluded from the trials due to various reasons, i.e. disease detected during hospitalization, such as tuberculosis, chronic diarrhoea, parasitic infestation which could otherwise influence the trial. The others died or were discharged at the request of their parents before the scheduled time of 4 weeks was finished.

The nutriftional status was evaluated weekly unitil approximately 8 weeks of hospitalization. During the entire trial only milk as the sole food was given.

\section{Results}

The critenia used for rating growth increase, after the edema has been substracted, are as follows : 
Excellent: if the increase of body weight within 1 month (4 weeks) divided by the natural optimal increase reflected by body weight and age is more than one.

Example:

A 1-year-olid girl, with a body weight of $5 \mathrm{~kg}$ on admission, was hospitalizzed for 8 weeks. On discharge the body weight was $7 \mathrm{~kg}$, so the average increase of body weight within 1 month (4 weeks) was $1000 \mathrm{gm}$.

The Indonesian standard of optimal monthly increase of a child with a body weilght of $5 \mathrm{~kg}$ regarded as a healthy child of the first trimester of age is $750 \mathrm{gm}$.

Average increase of b.w. (1 month)

Optimal increase (1 month)

$=\frac{1000}{750}=>1$

The result of this child is considered to be excellent.

$G \circ \circ d$ : if the ratio obtained according to the above mentioned calculations is approximately 1 .

Example:

A 2-year-old boy, with a body weight of $6.5 \mathrm{~kg}$ on admission, was hospitalized for 8 weeks. On discharge the body weight was $7.4 \mathrm{~kg}$, so the average increase of body weight within 1 month (4 weeks) was $450 . \mathrm{gm}$.
The natural optimal monthly increase of a child' with a body weight, of $6.5 \mathrm{~kg}$ - regarded as healthy child of the second itrimester of age - is $\mathbf{4 5 0}$ gm.

Average increase of ib.w. (1 month)

Optimal increase (1 month)

$=\frac{450}{450}=1$

The results is considered to be good.

Poor: if the ratio is less than one.

Example :

A 3-year-old boy, with a body weight of $8.5 \mathrm{~kg}$ on admissiton, was hospitalized' for 8 weelss. On discharge the body weight was $9.0 \mathrm{~kg}$, so the average increase of body weight was $9.0 \mathrm{~kg}$, so the average increase of body weight within 1 month (4 weeks) was $250 \mathrm{gm}$. The natural optimal monthly increase of a child with a body weight of $8.5 \mathrm{~kg}$ - regarded as a healthy child of the third trimester of age - is $350 \mathrm{gm}$.

Average increase of b.w (1 month) Optimal increase (1 month)

250

$=\frac{}{350}=<1$.

The result is considered to be poor.

Table 1 shows the effect of E.M. on PCM chilldren : excellent on 12 
out of 14 patients $(81.7 \%)$, good on 2 out of 14 patients $(14.3 \%)$ and poor on none.

Tablo 2 shows the effeot of E.M. on PCM children : excellent on 1 out of 11 patients $(9.1 \%)$, good on 4 out of 11 pativenits $(36.4 \%)$ and poor on 6 out of 11 patients $(54.5 \%)$.

\section{Discussion}

Disaccharidases are found in the brushborder lining the luminal surface of the initestinal epithelium (Miller and Crane, 1961) and therefore are liable to be affected by any dissorder where the intestinal mucosa is damaged. Examples of this include pratein calorie malnutrition, gastroenteritis and some parasitic infestations.

Normally, lactase is present in a lower concentration as compared with other brushborder disaccharidase (Dahlquist, 1964). It is also the last completely recovery of the following mucosal damage (Plotkin and Isselbacher, 1964). Consequently, lactase deficiency is the most important type of the secondary disaccharidase defiliency.

Our intestinal biopsy stuidy showed that Jakarta children with severe PCM have notable villous atrophy in the upper small intestine. The incidence of damage in grades II and III was $56.3 \%$ (9 out of 16 cases) and in grades IV, V, and VI $43.7 \%$ (7 out of 16 cases) as compared with $10.5 \%$ and $89.5 \%$ respectively in Kampala for the same grades (Stanfield, 1965).

So, in treating PCM, a lactose low or free diet is recommended. From our present study we had good $(43.3 \%)$ to excellent $(85.7 \%)$ results in treating PCM with low lactose millk. From the 12 out 14 cases $(85.7 \%$ with excellent and 2 cases (14.3\%) with good results within one month.

- 1 case showed an increase of $1.600 \mathrm{gm}$ of body weight

- 4 cases showed an increase of 1.100 to $1.500 \mathrm{gm}$ of body weight

- 8 cases showed an increase of 500 to $700 \mathrm{gm}$ of body weight and

- 1 cases showed an increase of 350 gm of body weight.

On the other hand, the results of EML to the other 11 PCM children were for the majority poor ( 6 out of 11 cases or $54.5 \%$ ). Only 1 case gave an excellent result, whereas the other 4 remaining cases gave rather good results $(36.4 \%)$. The increase in body weight within one month of these 11 patients treated with EML varied only from $100 \mathrm{gm}$ to $400 \mathrm{gm}$. In general, the conclusion drawn from this trial is that low lactose milk in PCM children gives significantly betiter results and this might be seriously considered in the management of PCM in the future. 
TABLE 1 : Effect of "Low Lactose Mis?" * ch protein cailirie malnutrition childrem.

\begin{tabular}{|c|c|c|c|c|c|c|c|c|}
\hline \multirow{2}{*}{ No. } & \multirow{2}{*}{ Name } & \multirow{2}{*}{$\begin{array}{c}\text { Age } \\
\text { (years) }\end{array}$} & \multirow{2}{*}{$\begin{array}{c}\text { Bady weight } \\
\text { on admission } \\
(\mathrm{kg})\end{array}$} & \multirow{2}{*}{$\begin{array}{c}\text { Duratirn of } \\
\text { hospitaliza- } \\
\text { tion } \\
\text { (weeks) }\end{array}$} & \multirow{2}{*}{$\begin{array}{c}\mathrm{HD} \\
(\mathrm{gm} \%)\end{array}$} & \multirow{2}{*}{$\begin{array}{l}\text { Alb/glob. } \\
\text { ratio }\end{array}$} & \multirow{2}{*}{$\begin{array}{c}\text { Increase } \\
\text { of } \mathrm{BW} / 4 \mathrm{w} \text {. } \\
(\mathrm{gm})\end{array}$} & Results \\
\hline & & & & & & & & E. G. P. \\
\hline 1. & $\mathbf{B}$ & $5 / 12$ & 3.4 & 8 & 10.5 & $3.15: 3.30$ & 800 & $+\ldots-$ \\
\hline 2. & $\mathrm{D}$ & $15 / 12$ & 4.0 & 8 & 8.2 & $3.25: 3.15$ & 700 & -+- \\
\hline 3. & $\mathbf{S}$ & $11 / 12$ & 7.5 & 12 & 9.9 & $2.85: 2.60$ & 350 & -+- \\
\hline 4. & $\mathrm{H}$ & $1 \% / 2$ & 5.0 & 7 & 9.9 & $2.67: 2.65$ & 900 & $+1-$ \\
\hline 5. & $N$ & 2 & 5.0 & 12 & 9.4 & $2.73: 3.10$ & 900 & +-- \\
\hline 6. & $\mathrm{~W}$ & 1 & 5.4 & 10 & 9.5 & $3.17: 2.66$ & 950 & +-- \\
\hline 7. & $\mathbf{s}$ & 2 & 6.4 & 9 & 5.4 & $3.09: 2.73$ & 1.500 & +-- \\
\hline 8. & $\mathbf{S}$ & $7 / 12$ & 4.4 & 9 & 9.7 & $2.99: 2.50$ & 800 & $+-\cdots$ \\
\hline 9. & A & $16 / 12$ & 6.9 & 11 & 9.0 & $2.06: 2.42$ & 1.100 & $+\ldots$ \\
\hline 10. & $\mathbf{S}$ & $15 / 12$ & 4.7 & 9 & 7.4 & $3.13: 2.47$ & 1.200 & +-- \\
\hline 11. & $J$ & $12 / 12$ & 6.6 & 9 & 7.8 & $2.76: 2.65$ & 900 & $+-\ldots$ \\
\hline 12. & $\mathrm{D}$ & $16 / 12$ & 4.4 & 10 & 9.4 & $2 . .24: 1.95$ & 1.600 & +-- \\
\hline 13. & 0 & 3 & 5.0 & 10 & 8.0 & $3.18: 3.32$ & 800 & +-- \\
\hline 14. & $\mathbf{M}$ & $10 / 12$ & 5.1 & 4 & 10.0 & $3.19: 2.78$ & 1.200 & +-- \\
\hline
\end{tabular}

" "Eiwit Melk" (E.M.).

$\mathbf{E}=$ Excellent; $\mathrm{G}=$ Good; $\mathrm{P}=$ Poor

$\mathbf{G}=$ Good

$\mathbf{P}=$ Paor 
TABLE 2: Effect of "Normal Formula Milk" (**) on protein calorie malnutrition children

\begin{tabular}{|c|c|c|c|c|c|c|c|c|}
\hline \multirow{2}{*}{ No. } & \multirow{2}{*}{ Name } & \multirow{2}{*}{$\begin{array}{c}\text { Age } \\
\text { (years) }\end{array}$} & \multirow{2}{*}{$\begin{array}{c}\text { Body weight } \\
\text { on admission } \\
(\mathrm{kg})\end{array}$} & \multirow{2}{*}{$\begin{array}{c}\text { Duration of } \\
\text { hospitaliza- } \\
\text { tion } \\
\text { (weeks) }\end{array}$} & \multirow{2}{*}{$\begin{array}{c}\mathrm{Hb} \\
(\mathrm{gm} \%)\end{array}$} & \multirow{2}{*}{$\begin{array}{l}\text { Alb/glob. } \\
\text { ratio }\end{array}$} & \multirow{2}{*}{$\begin{array}{c}\begin{array}{c}\text { Increase } \\
\text { of } \mathrm{BW} / 4 \mathrm{w} \\
(\mathrm{gm})\end{array}\end{array}$} & \multirow{2}{*}{$\begin{array}{r}\text { Resulls } \\
\text { E. G. P. }\end{array}$} \\
\hline & & & & & & & & \\
\hline 1. & A & $14 / 12$ & 6.5 & 8 & 9.9 & $3.05: 230$ & 100 & $-\cdots+$ \\
\hline 2. & $D$ & $25 / 12$ & 6.5 & 7 & 9.8 & $3.05: 2.35$ & 400 & -+- \\
\hline 3. & $\mathbf{S}$ & $46 / 12$ & 6.5 & 4 & 8.3 & $2.83: 2.52$ & 200 & --+ \\
\hline 4. & $E$ & $16 / 12$ & 5.8 & 5 & 6.5 & $3.03: 2.88$ & 400 & -+- \\
\hline 5. & 8 & $16 / 12$ & 7.6 & 4 & 10.0 & $2.24: 2.63$ & 400 & $-\ldots+$ \\
\hline 6. & $\mathrm{D}$ & $13 / 12$ & 6.6 & 8 & 9.2 & $2.83: 2.57$ & 750 & +-- \\
\hline 7. & M & $2^{6 / 12}$ & 5.7 & 5 & 7.9 & $3.11: 3.18$ & 340 & --+ \\
\hline 8. & $\mathbf{S}$ & $11 / 12$ & 5.6 & 8 & 5.6 & $2.32: 2.77$ & 300 & $-\cdots+$ \\
\hline 9. & $\mathbf{T}$ & $16 / 12$ & 7.0 & 3 & 7.0 & $3.18: 3.22$ & + & --+ \\
\hline 10. & $\mathbf{M}$ & $15 / 12$ & 6.7 & 8 & 10.0 & $2.98: 2.57$ & 400 & -+- \\
\hline 11. & $\mathbf{A}$ & 2 & 6.8 & 6 & 7.8 & $2.32: 2.65$ & 500 & -+- \\
\hline
\end{tabular}

** "Eiwit Melk" + lactose (EML)

$\mathrm{E}=$ Excellent

$\mathrm{G}=\mathrm{Good}$

$\mathrm{P}=$ Poor 


\section{REFERENCES}

1. DAHLQVIST, S.: Method for assay of intastinal disaccharidases. Analyt Biochem $7: 18$ (1964).

2. DE HAAS, J.H. and MEULEMANS, $O$. Melk in het bijzonder als Zuigelingenvoedsel, tweede druk (1940) Batavia.

3. MILLER, D. and CRANE, R.K.: The Digestive function of the ephithelium of the small intestine. Biochem. et biophys. Acta 52 : 293 (1961).

4. PLOTKIN, G.R. and ISSELBACHER, K.J.: Secondary disaccharidase deficiency in malabsorption states. N. Engl. J. Med. 27 : 1033 (1964).
5. STANFTELD, J.P., HUTT, M.S.R. and TUNNICLIFEE, R. : Intestinal biopsy in Kwashiorkor. Lancet ii : 519 (1965).

6. SUHARJONO, SUNOTO, ASWITHA DAMAJANTI, SADIKIN DARMAWAN and COTTOM, D.G.: Small intestine biopsy in Protein Calorie Malnutrition and Celiac children. Paediatr. Indones. 11 : 75 (1971).

7. SUNOTO, SUHARJONO, CYSCA, LEMBONG, ASWITHA BUDIARSO and SAMSUDIN: Lactose loading test on PCM children. Paediatr. Indones. 2: 13 (1973). 